\title{
Effect of Different Natural Feed Additives Compared to Antibiotic on Lipid Profile of Broiler Chicks Under High Temperature
}

\author{
Hind. A. A. Elagib ${ }^{1}$, Saadia. A. Abbas ${ }^{2}$, Bakheit M. Dousa ${ }^{3}$, Huwiada E E Malik ${ }^{4}$, Khalid M. Elamin ${ }^{5}$ \\ 1,2,3,4 Department of Poultry Production, Faculty of Animal Production, University of Khartoum - Sudan \\ ${ }^{5}$ Department of Genetics and Animal Breeding, Faculty of Animal Production, University of Khartoum- Sudan
}

\begin{abstract}
This experiment was conducted to investigate the effect of two different medicinal plants, cumin (Cuminumcyminum), fenugreek (Trigonellafoenum-graecum) as natural feed additives with antibiotic (Doxystin)on the serum lipid profile of broiler chicks. One hundred and sixty, (one day-old) broiler chicks were randomly divided into six groups of similar mean weight, each with four replicates of ten chicks. The control group received broilers basal diet. For the other groups, the basal diet was supplemented with one of the following: the antibiotic (Doxystin) as $0.5 \%$ or one of the spices, $C$. cyminum, $T$. foenum-graecum as $2 \%$. Serum lipid profile in the broiler chicks was affected as follows, total cholesterol concentration was significantly $(P<0.05)$ decreased in all groups received spices diet compared to doxystin and control groups. Also there was significant $(P<0.05)$ decrease in the serum LDL-C concentration of T.foenum-graecum treated groupcompared to doxystin and control groups. Also the HDL-C concentration showed significant $(P<0.05)$ decrease in all experimental groups compared to the control group. Spices treatments resulted in significant decrease of the total cholesterol and the LDL-C fraction similar to antibiotic treated animals. This experiment concluded that C. cyminum, T. foenumgraecum could be used as promising hypocholesterolemicagents that can improve meat quality.
\end{abstract}

Keywords: cholesterol, spices,triglyceride, broiler

\section{Introduction}

The alternative feed supplement in broiler chicken production has stimulated the attention of the producer as the use of antibiotics as growth promoters has been ceased. Aromaticplants and essential oils extracted from these plants became interesting due to their effects as antimicrobial agents [1], antioxidants [2] ,hypocholesterolemic agents [3] and as stimulators of animals digestive enzymes [4]. The cholesterol lowering property of essential oil constituents has been attributed to a suppressing effect of the enzyme 3hydroxy-3-methylglutaryl coenzyme A reductase [5], which is considered to be limiting in cholesterol synthesis [6] . Cholesterol found in the blood plasma in the form of lowdensity lipoprotein (LDL) and high-density lipoprotein (HDL) [7]. Cholesterol is a major constituent of gallstones. However, its chief role in pathologic processes is as a factor in the genesis of atherosclerosis of vital arteries, causing cerebrovascular, coronary, and peripheral vascular disease [8].

Poultry meat has many desirable nutritional characteristics such as low lipid content and relatively high concentrations of polyunsaturated fatty acids [9] .Knowledge of lipid biochemistry is necessary in understanding many important biomedical areas, e.g., obesity, diabetes mellitus, atherosclerosis, and the role of various polyunsaturated fatty acids in nutrition and health [6].

The present study wascarried out to assess the effect of supplementation of dietary powdered spicesor antibiotic growth promoter (Doxystin) on the lipid profile of broiler chicks.

\section{Material and Methods}

Two hundred and forty, one day old, unsexed white broilers (Cobb - strain) obtained from El- Garr company and transferred to the Faculty of Animal production. One hundred and sixty chicks adapted to the basal diet for one day then divided in to four groups, A, B, C, D, , randomly. Each group replicated in a four pens, each pen contained ten birds.

The bird fed starter diet for the first three weeks and finisher diet for next three weeks (table.1). Water and diet freely accessed. The light was maintained for 24 hours per day naturally and artificially. Six dietary treatment were fed to the birds , group (A) fed basal diets as control, group (B) fed basal dietplus the antibiotic (Doxystin) as $0.5 \%$, group (C) fed basal diet plus C.cyminum powder as $2 \%$, group (D) fed basal diet plus $T$. foenum-graecum powder as $2 \%$

The blood was collected from the jugular vein during slaughter from the three birds from each replicate from different treatments. Fifteen $\mathrm{ml}$ of blood was drawn into clean test tubes and was labeled. The blood was allowed to clot and serum was separated by centrifugation at 3000 r.p.m for 5 minutes. Then serum was transferredinto plain containers and used for the estimation of blood parameters.

\section{Biochemical estimation}

Serum samples have been collected at 42 day of age for the estimation of total cholesterol, HDL, LDL, Triglyceride. The cholesterol concentration was estimated by an enzymatic method which measures the total cholesterol concentration in the serum as described by [10]. 


\section{International Journal of Science and Research (IJSR) \\ ISSN (Online): 2319-7064}

Index Copernicus Value (2015): 78.96 | Impact Factor (2015): 6.391

High density lipoprotein-cholesterol (HDL-c) in the sample was determined according to the precipitation method described by [11].

To calculate low density lipoprotein-cholesterol (LDL-c) in $(\mathrm{mg} / \mathrm{L})$ the following formula was used:

LDL cholesterol $=$ Total cholesterol - Triglycerides $/ 5-$ HDL cholesterol

Triglycerides (TG) in the sample were determined according to the enzymatic colorimetric method described by [12] .

\section{Statistical Analysis}

The data were analyzed by one way ANOVA procedure according to SPSS computing software program. Each test was conducted at $5 \%$ level of significant.

\section{Results}

Table (2) illustrates the effect of supplementing $2 \%$ of dietary powdered spicesand $0.5 \%$ doxystin on broiler chicks serum total cholesterol concentration. The results showed significant $(\mathrm{P}<0.05)$ decrease in the mean values of serum total cholesterol concentration in group of birds fed spices compared to those fed doxystin and control groups. Except in the C.cyminum treated group, there was a significant $(P<$ $0.05)$ decrease in serum LDL concentration in $T$. foenumgraecum treated group compared to the control group. Also there was a significant $(\mathrm{P}<0.05)$ decrease observed in LDL concentration in spices treated groups compared to the doxystin treated group and there was a noticeable numerical decrease in the serum LDL concentration of the C.cyminum treated group compared to the control group. On the other hand there was no significant difference observed within spices treated groups.

The results showed significant $(\mathrm{p}<0.05)$ decrease in the level of HDL concentration in the experimental groups compared to the control. Also there was no significant difference observed within the experimental groups when compared together.

There was no significant change reported between the experimental groups and control on broiler chicks' serum triglycerides (TG) and Very low density lipoprotein cholesterol (VLDL) concentrations. But there was a numerical decrease observed in the mean values of TG and VLDL concentrations in all treated groups compared to the control group.

\section{Discussion}

The lipid profile typically includes:Total cholesterol, High density lipoprotein cholesterol (HDL-C) often called good cholesterol; Low density lipoprotein cholesterol (LDL-C) often called bad cholesterol, Triglycerides (TG). An extended profile may also include: Very low density lipoprotein cholesterol (VLDL-C) [13] .

[14] identified the effect of using C.cyminum on the blood traits of broilers. He found that chicks fed diet supplemented with $1 \%$ C.cyminum resulted in a significant decrease in the level of cholesterol in blood serum compared to the control group. The decrease in the level of cholesterol due to the active compound that found in C.cyminum which acts as inhibitors to the active enzyme hepatic 3- hydroxyl-3 methyglutaryl coenzyme A (HMG-CoA) that synthesized the cholesterol [15]. This effect is in line with [16], who reported that, the spices mixture containing piperine, Z.officinale andC.cyminum in favorably stimulated secretary rate of bile acids. Also these findings are correlated with [17] who found that, C.cyminum decreased significantly the plasma level of cholesterol.

[18] found that, the level of plasma total cholesterol was decreased significantly $(\mathrm{P}<0.05)$ after administration of $4 \%$ and $8 \%$ T.foenum-graecumseeds powder compared to the control. This in line with the present work and the finding reported by [19] who reported that, feeding 5\% T.foenumgraecumseeds powder for 2 weeks to hypercholesterolemic rats resulted in a reduction of plasma total cholesterol, which is attributed to an increased conversion of hepatic cholesterol to bile salt which is lost in the feces together with fenugreek fiber and saponins. Also the T. foenumgraecumseeds powder improves insulin secretion, which has inhibitory action on HMG-CoA reductase, a key enzyme responsible for the synthesis of cholesterol [20]

The level of serum LDL-c decreased significantly $(\mathrm{P}<0.05)$ in broiler chicks after feeding $2 \%$ powdered T.foenumgraecum compared to the control group. But there was numerical decreased in the C.cyminum treated group compared to control group (Table. 2).

There was also significant $(\mathrm{P}<0.05)$ decrease in the level of serum LDL-c concentration in spices treated groups compared to doxystintreated group. Where as, there was no significant difference observed within spices treated groups. On the other hand, doxystin group showed the highest concentration value compared to the other groups.[21] found that, inclusion of various levels of $0.2,0.4$ and $0.8 \mathrm{~g} / \mathrm{kg}$ C.cyminum Essential Oil in broiler diets decreased insignificantly LDL concentrations at $\mathrm{d} 28$. This agrees with finding reported in the present work. Also T.foenumgraecum treated group results agrees with [18] who found that the level of plasma LDL-c of the rats was decreased significantly $(\mathrm{P}<0.05)$ after administration of $4 \%$ and $8 \%$ T.foenum-graecumseeds powder compared to the control. This in line with[19] who reported that, feeding 5\% T.foenum-graecumseeds powder for 2 weeks to hypercholesterolemic rats, resulted in a reduction of plasma LDL-c.

There was a significant $(\mathrm{p}<0.05)$ decrease in the level of HDL concentration in the experimental groups compared to the control. Also there was no significant difference was observed within the experimental groups.In the other studies [21] found that, inclusion of various levels of $0.2,0.4$ and $0.8 \mathrm{~g} / \mathrm{kg}$ C.cyminum Essential Oil in broiler diets decreased insignificantly HDL concentrations at $\mathrm{d} 28$.

Also [22] Sharma et al, (1991) investigated 15 nonobese, asymptomatic, hyperlipidemic adults. After the subjects had ingested $100 \mathrm{~g}$ defatted T.foenum-graecum powder per day for three weeks, there is a slight decreases in HDL levels 


\section{International Journal of Science and Research (IJSR) \\ ISSN (Online): 2319-7064}

Index Copernicus Value (2015): 78.96 | Impact Factor (2015): 6.391

were noted. Similarly [18] found that, the level of plasma HDL-c of the rats was decreased significantly $(\mathrm{P}<0.05)$ after administration of $1 \%$, and increased significantly $(\mathrm{P}<0.05)$ after administration of $4 \%$ and $8 \%$ T.foenum-graecumseeds powder compared to the control.

Nosignificant change between the experimental groups and control group serum triglycerides (TG) and Very low density lipoprotein cholesterol (VLDL) concentrations. But there was a numerical decrease observed in the mean values of TG and VLDL concentrations in the experimental groups compared to the control group.

In the other study, [21] found that, inclusion of various levels of $0.2,0.4$ and $0.8 \mathrm{~g} / \mathrm{kg}$ C.cyminum Essential Oil in broiler diets decreased insignificantly $\mathrm{TG}$ and VLDL concentrations at $\mathrm{d} 28$. Also these findings correlated with [17] who found that, C.cyminum decreased significantly the plasma level of TG.

[18] found that, the levels of plasma VLDL cholesterol and TG of the rats was decreased insignificantly after administration of $4 \%$ and $8 \%$ T.foenum-graecumseeds powder compared to the control.

\section{Conclusion}

Spices treatments resulted in significant decrease in the serum cholesterol and LDL-C compared to the doxystin treated and the control groups. The spicesare promising as hypocholesterolaemic agents.Using spices as additive is sure without any risk regarding antibiotic resistance or residues in animal products.

\section{References}

[1] Burt, S. A. (2004). Essential oils: their antibacterial properties and potential applications in foods: a review. Inter J. Food Microbiol. 94: 223-253.

[2] Botsoglou, N. A.; Florou-Paner, P.; Chiristaki, E.; Fletouris, D.J.; Spais, A.B. (2002). Effect of dietary oregano essential oil on performance of chickens and on iron-induced lipid oxidation of breast, thigh and abdominal fat tissue. Br Poult Sci. 43: 223-230.

[3] Craig, W.J. (1999). Health-promoting properties of common herbs. Am J of ClinNutr 70: 491-499.

[4] Cabuk, M.; Alcicek, A.; Bozkurt, M.; Imre, N.; (2003). Antimicrobial properties of the essential oils isolated from aromatic plants and using possibility as alternative feed additives. In: II. National Animal Nutrition Congress 18-20 September 184-187

[5] Elson, C. E.; Underbakke, G. L.; Hanson, P.; Shrago, E.; Wainberg, R. H. andQuereshi, A. A. (1989). Impact of lemongrass oil an essential oil on serum cholesterol. Lipids 26: 677-679.

[6] Murray, R. K., Granner, D. W., Mayes, P. A. and Rodwell, V. W. (2006). Harper's Illustrated Biochemistry.26th ed.McGraw-Hill campanies. Beirut, Lebanon.9: 73, 14:111, 26: 219-20,583-4.

[7] Voet, D. and Judith , G. V. (2004). Biochemistry . $3^{\text {rd }}$ .ed .John Wiley and Sons, Hoboken.12: 385, 439-46.
[8] Murray, R. K., Granner, D. W., Mayes, P. A. and Rodwell, V. W. (2000) . Harper biochemistry. $25^{\text {th }}$ ed. Pub. Applton and Lang. U. S. A.

[9] Igene, J.O.; Pearson, A.M.; (1979). Role of phospholipids and triglycerides in warmed-over flavor development in meat model systems. J of Food Sci. 44: 1285-1290.

[10] Richmond, W. (1973). Preparation and properties of a cholesterol oxidase from Nocordiasp .and its application to the enzymatic assay of total cholesterol in serum . Clin .Chem., 19: 1350 - 1356.

[11] Friedewald, W.T (1972). Estimation of the Concentration of Low-Density Lipoprotein Cholesterol in Plasma, Without Use of the Preparative Ultracentrifuge. Clin. Chem. U.S. 18: 499.

[12] Bucolo, G. and David, H. (1973). Quantitative determination of serum triglycerides by the use of the enzymes.Cli. Chem. 19: 475.

[13] Krames, (2010). Total Protein and A/G Ratio Tests. Mount Nittany Medical Center. 814: 231-7000.

[14] Galib, A.M. (2010). Effect of Feeding Cumin (Cuminumcyminum) on the Performance and Some Blood Traits of Broiler Chicks.Pakistan Journal of Nutrition. 1: (9) 72-75.

[15] Crowell, P.L. (1999). Prevention and therapy of cancer by dietary monoterpenes. J. Nutr. 129: 775s-778s.

[16] Platel, K.; Rao, A.; Saraswathi, G.; Srinivasan, K. (2002). Digestive stimulant action of three Indian spices mixes in experimental rats. J. PubMed. Nahrung. 46: 394-398.

[17] Aruna, K.; Rukkumani R.; Suresh, P.Varma; Venugopal, P. Menon (2005). Therapeutic role of Cuminumcyminum on ethanol and thermally oxidized sunflower oil induced toxicity. Phytotherapy Research. 5: (19) $416-421$.

[18] Awad M. H. E. (2009). the effect of Trigonellafoenumgraecum $L$ seeds powderon lipid profile Cholesterol fed rats. MSc. Thesis $U$ of Khartoum. Pp. 25

[19] Molham, A. and Amala, R., (1998). Antidiabetic and hypocholesterolaemic effect of fenugreek. Phytother. Res. 12: 233-242.

[20] Petit, P.; Sauvaire, Y. and Hillaire, D. (1995). Insulin stimulating effect of an original amino acid, 4hydroxyisoleucine purified from fenugreek, Trigonellafoenum-graecum L seeds. Diab. 38: 1-101.

[21] Aami-Azghadi, M.; Abolghasem, G.; Hasan, K. and Sedghi, M. (2010). Comparison of Dietary Supplementation with Cumin Essential Oil and Prebiotic Fermacto on Humoral Immune Response, Blood Metabolites and Performance of Broiler Chickens. J. Global Veterinaria. IDOSI Publications. 4 (4): $380-387$.

[22] Sharma A, Chakraborti KK, Handa SS. (1991) Antihepatotoxic activity of some Indian herbal formulations as compared to silymarin. Fitoterapia 62: 229-235. 


\section{International Journal of Science and Research (IJSR)}

ISSN (Online): 2319-7064

Index Copernicus Value (2015): 78.96 | Impact Factor (2015): 6.391

Table 1: Composition of the basal diet fed to the experimental birds

\begin{tabular}{|c|c|c|c|c|}
\hline $\begin{array}{l}\text { Ingredients } \\
\text { As percentage }\end{array}$ & $\begin{array}{c}\% \\
(1-3 w k s) \\
\text { Starter } \\
\text { Control }\end{array}$ & $\begin{array}{c}\% \\
\text { (4-6wks) } \\
\text { Finisher } \\
\text { Control }\end{array}$ & $\begin{array}{c}\% \% \\
(1-3 w k s) \\
\text { Starter } \\
\text { Spices }\end{array}$ & $\begin{array}{c}\% \\
\text { (4-6wks) } \\
\text { Finisher } \\
\text { Spices }\end{array}$ \\
\hline Sorghum & 65.1 & 66.5 & 63.1 & 64.5 \\
\hline Groundnut meal & 18.7 & 13.5 & 18.7 & 13.5 \\
\hline Sesame meal & 10 & 12.7 & 10 & 12 \\
\hline Super concentrate & 5 & 5 & 5 & 5 \\
\hline Lime stone & 0.9 & 0.9 & 0.9 & 0.9 \\
\hline Salt & 0.25 & 0.25 & 0.25 & 0.25 \\
\hline Lys & 0.04 & 0.06 & 0.04 & 0.06 \\
\hline Meth & 0.01 & 0.01 & 0.01 & 0.01 \\
\hline Vegetable oil & 0 & 1.08 & 0 & 1.8 \\
\hline Spices & 0 & 0 & 2 & 2 \\
\hline Total $100 \%$ & 100 & $\overline{100}$ & $\overline{100}$ & 100 \\
\hline
\end{tabular}

*Broiler Super concentrate contains (\%): CP 40, CF 1.5, ME 2122 Kal/kg, fat 3,Lysine13.5, Methionine 5.9, Methionine+cystine6.25,P 4.6, Ca 6.8, Na 1.5. Vitamins supplied per Kg of diet: Vit. A, 250000 IU; Vit. D3, 60 000 IU; Vit. E, $800 \mathrm{mg}$; Vit. K3,60 mg; Vit. B1, 30mg; Vit. B2, $100 \mathrm{mg}$; Vit. B6, $50 \mathrm{mg}$; Vit. B12, $300 \mathrm{mg}$; Vit. C, $4000 \mathrm{mg} ; \mathrm{Niacin}, 800 \mathrm{mg}$; Folic acid,30mg; Biotin, 30mg;Choline chioride,3000mg; Copper, 30 mg; Iron, 100mg; Manganese, 160mg; Zinc,100mg; Iodine,1.3mg; Selenium, 5mg; Cobalt, 1.2mg; Fytase enzyme, 15000; Antioxidant.

Table 2: Effect of dietary supplementation of C.cyminum, T. foenum-graecumand doxystin on broiler chicks serum lipid profile

\begin{tabular}{|c|c|c|c|c|}
\hline Parameter & Control & Doxystin & C.cyminum & T.foenum-graecum \\
\hline $\begin{array}{c}\text { Cholesterol } \\
(\mathrm{mg} / \mathrm{dl})\end{array}$ & $314.72^{\mathrm{a}} \pm 19.42$ & $287.23^{\mathrm{a}} \pm 54.56$ & $171.43^{\mathrm{b}} \pm 30.32$ & $140.04^{\mathrm{b}} \pm 14.72$ \\
\hline HDL $(\mathrm{mg} / \mathrm{dl})$ & $179.69^{\mathrm{a}} \pm 8.02$ & $69.26^{\mathrm{b}} \pm 11.27$ & $89.1^{\mathrm{b}} \pm 21.11$ & $80.23^{\mathrm{b}} \pm 7.17$ \\
\hline LDL $(\mathrm{mg} / \mathrm{dl})$ & $128.51^{\mathrm{ab}} \pm 18.61$ & $160.76^{\mathrm{a}} \pm 40.06$ & $77.36^{\mathrm{bc}} \pm 9.97$ & $57.38^{\mathrm{c}} \pm 10.03$ \\
\hline TG(mg/dl) & $53.59^{\mathrm{a}} \pm 15.57$ & $42.45^{\mathrm{a}} \pm 8.55$ & $39.06^{\mathrm{a}} \pm 10.55$ & $35.66^{\mathrm{a}} \pm 8.07$ \\
\hline VLDL(mg/dl) & $10.72^{\mathrm{a}} \pm 2.7$ & $8.49^{\mathrm{a}} \pm 1.48$ & $7.81^{\mathrm{a}} \pm 1.83$ & $7.13^{\mathrm{a}} \pm 1.4$ \\
\hline
\end{tabular}

a, b, c : Row means with no common superscript differ significantly at $(\mathrm{P}<0.05)$. 